\title{
BIBLIOTECA Y ARCHIVO DE LA ACADEMIA DE LAS ARTES Y LAS CIENCIAS CINEMATOGRÁFICAS. LA GESTIÓN DE LA INFORMACIÓN AL SERVICIO DE LA PROMOCIÓN DEL CINE ESPAÑOL ${ }^{1}$
}

\author{
Antonia Salvador Benítez ${ }^{*}$ \\ Facultad de Ciencias de la Documentación. Universidad Complutense de Madrid.
}

\begin{abstract}
Resumen: El objetivo del presente trabajo es el conocimiento general del funcionamiento interno del servicio de Biblioteca y Archivo de la Academia de las Artes y las Ciencias Cinematográficas de España, sus objetivos y funciones, la tipología de sus fondos así como las técnicas de documentación aplicadas en su tratamiento y gestión. La información se ha obtenido mediante un trabajo de campo, examinando in situ las instalaciones y la documentación. Se ha diseñado un cuestionario y se ha realizado una entrevista con el personal responsable para conocer el tratamiento, difusión, uso y aplicaciones de la documentación generada por la Academia de Cine. Los resultados del estudio ofrecen información inédita sobre volumen, tipología y temática de los fondos, metodología documental, perfil de usuarios y aplicaciones de la documentación.

Palabras clave: Academia de las Artes y las Ciencias Cinematográficas de España; archivos de cine; bibliotecas especializadas; cine; documentación; documentación cinematográfica; difusión; gestión de la información; tratamiento documental.
\end{abstract}

Title: LIBRARY AND ARCHIVE OF THE ACADEMY OF MOTION PICTURE ARTS AND SCIENCES. THE INFORMATION MANAGEMENT FOR THE PROMOTION OF SPANISH CINEMA.

Abstract: The aim of this study is general knowledge of internal operation of the Library and Archive of the Academy of Motion Picture Arts and Sciences of Spain, its objectives and functions, the types of funds and the technical issues related to the documentary treatment and information management. The information was obtained through field work, examining in situ facilities and documentation of the Academy. It has designed a questionnaire and performed an interview with responsible personnel to know the processing, distribution, use and applications of the documentation generated by the Academy Film. The study results provide new information on volume, types and thematic funds, documentary methodology, profile of users and documentation applications.

Keywords: Academy of Motion Picture Arts and Sciences of Spain; archives of cinema; specialized libraries; cinema; documentation; film documentation; diffusion; documentary treatment; information management.

\section{INTRODUCCIÓN}

En noviembre de 1985 el productor Alfredo Matas convocaba en Madrid a un grupo de conocidas personalidades de la cinematografía para debatir y buscar soluciones a los problemas e incertidumbres que vivía el cine español en ese momento. De aquella reunión saldría el germen de una asociación, avalada por ochenta y siete firmas de profesionales, que daría lugar al nacimiento de la Academia de las Artes y las Ciencias Cinematográficas de España. En 1986 se presentó ante la opinión pública y a partir de aquel mismo momento comienza a desarrollar su actividad, que cumple ahora treinta años.

La Academia de las Artes y las Ciencias Cinematográficas de España es una asociación sin ánimo de lucro que agrupa a los profesionales dedicados a las distintas especialidades de la creación cinematográfica. Se crea para impulsar la promoción nacional e internacional del cine español, fomentar el progreso de las artes y las ciencias relacionadas con la cinematografía y analizar la situación de la industria y del cine de nuestro país a través de estudios e investigaciones.

Situada inicialmente en un piso de la calle Sagasta la Academia necesitaba disponer de un edificio propio que, constituyendo su sede oficial, permitiera conservar documentos y obras cinematográficas, disponer de una biblioteca especializada y, en definitiva, un espacio para la organización y celebración de actos, proyecciones, coloquios y exposiciones. En septiembre de 2001 el Ministerio de Cultura y la Academia firmaron un convenio de cooperación por el que se formalizaba la cesión de un edificio propiedad del Estado que sirviera a estos fines y se establecieron las líneas de colaboración para la promoción y conservación del cine español.

*asalvador@ccinf.ucm.es

Recibido: 6-02-2016; 2a versión: 17-02-2016; aceptado: 23-02-2016.

SALVADOR BENÍTEZ, A. Biblioteca y Archivo de la Academia de las Artes y las Ciencias Cinematográficas. La gestión de la información al servicio de la promoción del cine español. Anales de Documentación, 2016, vol. 19, $\mathrm{n}^{\circ} 1$. Disponible en: http://dx.doi.org/10.6018/analesdoc.19.1.249751. 
El edificio destinado a la sede de la Academia era un palacete residencial de principios de siglo XX propiedad del Estado y ubicado en el número 3 de la calle Zurbano, anteriormente sede del Fondo Español de Garantía Agraria (FEGA). Las obras de rehabilitación y acondicionamiento del edificio a sus nuevos fines y necesidades se realizaron entre 2004-2006. En enero de 2007 la entonces presidenta de la institución, Ángeles González-Sinde, recibió las llaves de la nueva sede de mano de Carmen Calvo, ministra de Cultura en aquel momento.

El proyecto de creación de la Biblioteca de esta institución surge gracias a la iniciativa de su sexto presidente, José Luis Borau, con el fin de convertir la Academia de las Artes y las Ciencias Cinematográficas de España en un centro de referencia obligada en el desarrollo y promoción del cine de nuestro país. Abierta al público en enero de 2010, la Biblioteca nace para ser una fuente permanente y activa de información y consulta, principalmente para sus académicos, instituciones y cualquier particular apasionado por el cine.

Los estudios y la investigación sobre documentación cinematográfica tienen un referente en la revista Cuadernos de documentación multimedia, con varios números monográficos sobre la materia: software, gestión digital y bases de datos cinematográficas (2001), filmotecas, archivos y medios de comunicación cinematográficos (2005, 2008) así como en el portal de investigación y documentación cinematográfica CineDocNet, proyecto de investigación de la Facultad de Ciencias de la Información de la Universidad Complutense. Así mismo en 2005 PH. Boletín del Instituto Andaluz del Patrimonio Histórico dedicó un número especial al patrimonio cinematográfico y las V Jornades de Documentació Audiovisual de 2008 tuvieron como eje central la documentación en este ámbito.

Son varios los autores que han estudiado aspectos diversos de la documentación aplicada al cine. Ejemplo son los trabajos sobre análisis del documento fílmico, foto fija y el cartel cinematográfico (López Hernández, 2003; Pintanel, 2010; Fernández Mellado, 2014; Zabala y Sánchez, 2014); las fuentes documentales y sus aplicaciones al trabajo cinematográfico (López Yepes, 2000; Cuadra Colmenares, 2007, 2013; Suarez Gonzalo, 2008); competencias y perfil del profesional de la documentación en este ámbito (Bailac y Catalá, 2003; López de Solís, 2013) y los centros de documentación, bibliotecas, fondos cinematográficos y filmotecas (López Yepes, 1992, 2006, 2008; Devesa, 2010; Torrado Morales, 2000; Valle Gastaminza, 2013; García y Alberich, 2014).

Tanto a nivel nacional como autonómico, las filmotecas constituyen sin duda uno de los principales centros de referencia para la investigación, conservación y difusión del patrimonio cinematográfico, sin embargo es muy poco conocida la labor de documentación, gestión y difusión que realizan otras instituciones vinculadas con la industria cinematográfica y su contribución a la investigación sobre la materia.

Es objetivo de este trabajo ofrecer una presentación general del funcionamiento interno de la Biblioteca y el Archivo de la Academia de las Artes y las Ciencias Cinematográficas de España, sus objetivos y funciones así como el análisis de la tipología de sus fondos y las técnicas de documentación aplicadas en su tratamiento y gestión. El interés del presente estudio viene determinado por la ausencia de investigaciones previas sobre los fondos y la gestión documental en la Academia de Cine a lo que se une la no disponibilidad de estas informaciones en publicaciones especializadas ni en la web institucional. La información que se ofrece en esta investigación ha sido obtenida mediante un trabajo de campo presencial, analizando in situ las instalaciones, la documentación y el sistema de gestión documental. Para ello se ha realizado una entrevista con el personal responsable (Anexo 1) y se ha diseñado un cuestionario (Anexo 2) para conocer el tratamiento, difusión, uso y aplicaciones de la documentación generada por la Academia de Cine.

\section{LA BIBLIOTECA DE LA ACADEMIA. CARACTERÍSTICAS Y TIPOLOGÍA DE FONDOS}

Tal y como consta en sus estatutos entre los objetivos de la Academia de Cine están el potenciar el nivel artístico, técnico o científico de las artes cinematográficas; promover la investigación en materia cinematográfica; el intercambio de información científica, artística y técnica entre sus miembros y entidades afines; la concesión de becas y premios anuales a los mejores trabajos de investigación y estudios relacionados con la cinematografía en España, así como la colaboración entre la Administración Pública y los profesionales relacionados con estas artes.

El proyecto de creación de la biblioteca se pondrá en marcha tras el traslado de la institución a la nueva sede de la calle Zurbano y viene a consolidar el papel de la Academia como agente activo en la investigación y promoción del cine español. La Biblioteca se abre al público en enero de 2010 para convertirse en una fuente de información y consulta dirigida principalmente a los académicos e instituciones dedicadas a la industria cinematográfica pero también para investigadores e interesados por el cine. Desde el año 2013 pertenece a la Red de Bibliotecas de la Comunidad de Madrid. 


\section{Biblioteca}

Información y consultan. Arehivo y Biblioteca

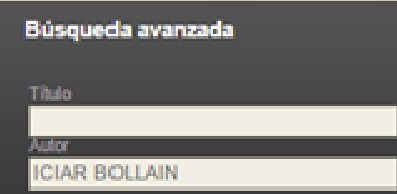

más información de la sede

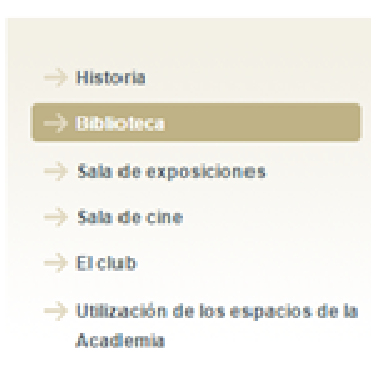

Mostrando \& resultados:

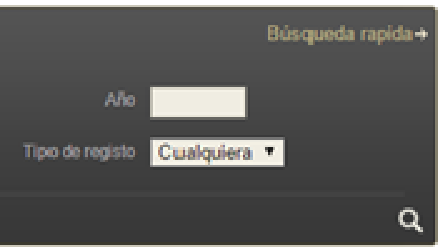

9) Flores de otro mundo

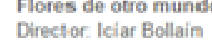
Hay motwot

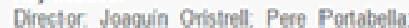
Awaro Del Amo David Trues: Gracis

0) Querejets; lisbel Coivet; Jost Ange

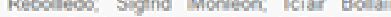
Chus Gutiersez, Vietor Manvel, Pedro Oles, Yoland Garcis Sertan, Victor Garcia Ledn otros.

6) Hola, zestbs sola? Dinctior felar Bollain

9) Katrand4, un espejo es el clelo Dinector felar Bollain

Ken Louch: un abservador solidatio leitar Bollain

a) Mataharis Direcior leiar Bollain

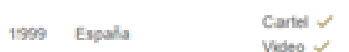

2004 Espols veleo carter 1 Wolso Guen Aule ado

\section{Cartel 5} Visteo -2 aso -
$1 \%$ Apdur

2007 Eapols

Figura 1. Catálogo de la Biblioteca. Formulario de búsqueda y pantalla de resultados.

Según los datos de 2014, dispone de una colección de acceso público integrada por 4670 monografías, 3685 películas de largometraje y 1408 cortometrajes. Cuenta además con una colección de documentos de acceso restringido constituida por 816 guiones (464 no publicados), 1712 bandas sonoras, más de 15000 fotografías de películas (2 608 en papel y 13287 diapositivas), 1744 carteles de cine, 3182 afiches en papel y material gráfico digital de 1330 películas. 


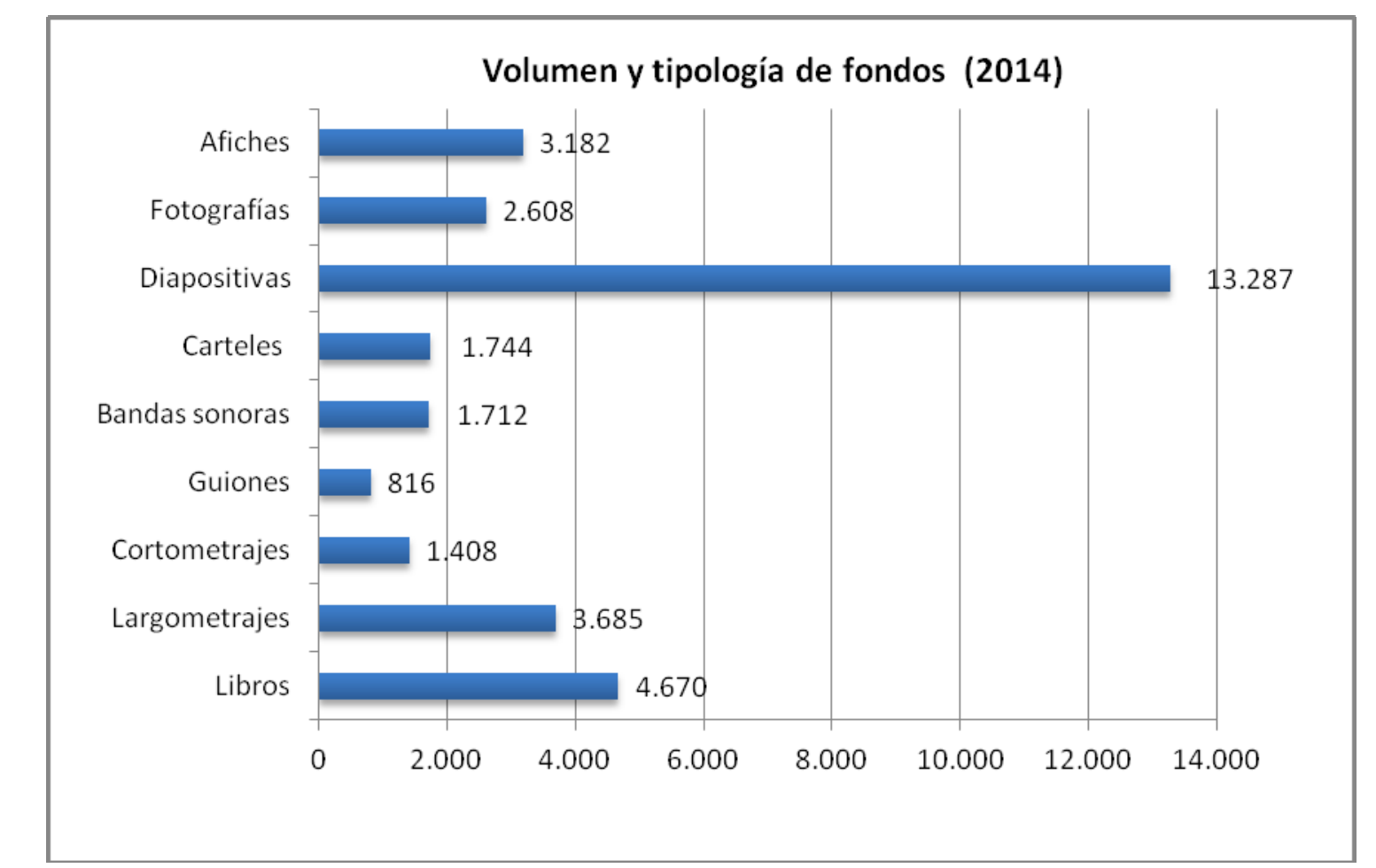

Grafico 1. Volumen y tipología de fondos documentales (2014). Fuente: Elaboración propia a partir de los datos facilitados por la Academia de Cine.

También se encuentran varios legados personales que han donado profesionales y actores, entre ellos: la documentación de la actriz y cantante Imperio Argentina (1906-2003); la actriz Raquel Rodrigo (1915-2004); el crítico de cine Juan Carlos Frugone (1938-2009); el diseñador artístico Eduardo Torre de la Fuente (1919-2009); una colección de guiones donados por el director artístico Gil Parrondo y una colección de libros de cine donados por el programa de radio sobre cine "Lo que yo te diga” (Cadena Ser), entre otros conjuntos.

Junto a estos fondos, destaca la extensa documentación propia generada por la Academia de Cine que incluye toda la documentación gráfica de los Premios Goya, galardones, homenajes y eventos que la institución ha celebrado a lo largo de sus treinta años de historia. A este conjunto documental dedicaremos los epígrafes siguientes.

\section{EL ARCHIVO DE LA ACADEMIA DE CINE. ESTRUCTURA Y CONTENIDO}

El Archivo de la Academia reúne la documentación generada por la institución en el ejercicio de sus funciones, desde su creación en 1986 hasta la actualidad. El origen y la gestión del archivo responden a uno de los objetivos fundacionales de la Academia como es la concesión de los premios anuales a los mejores trabajos de cada una de las especialidades de la cinematografía así como una serie de galardones de reconocimiento a otros ámbitos profesionales ligados al cine que se detallan a continuación:

- Medalla de Oro (1986 - actualidad). Reconocimiento a los profesionales que han contribuido a mejorar el cine español en el aspecto industrial o artístico. Se concede desde 1991, aunque en 1986 se celebró la primera ceremonia para homenajear a Vicente Casanova, considerado el primer galardonado con este premio.

- González Sinde (1998 - actualidad). Este premio toma el nombre del primer presidente de la Academia, José María González Sinde, cuyo papel resultó fundamental en los inicios de esta institución. Se concede a instituciones o personas que emplean el cine para la consecución de fines sociales.

- Muñoz Suay (1998 - actualidad). Reconocimiento a los mejores trabajos de investigación histórica sobre cine español que toma el nombre de uno de los intelectuales, críticos, cineastas e investigadores más importantes de nuestro país. Se crea en 1997 la concesión de este premio, se interrumpió en 2002 retomándose en 2008.

- Segundo de Chomón (2000 - actualidad). Galardón creado para reconocer el mérito de las aportaciones técnicas en la industria cinematográfica y toma su nombre de uno de los grandes pioneros del cine fantástico y de animación. ${ }^{2}$ 
- Alfonso Sánchez (2010 - actualidad). Premio de comunicación que toma el nombre del crítico cinematográfico y periodista Alfonso Sánchez ${ }^{3}$. Este galardón constituye un reconocimiento a la labor de los medios y sus profesionales por divulgar y promocionar el cine español.

- Premios Goya (1986 - actualidad). Reconocimiento a las películas españolas y a los profesionales que las han realizado en sus distintos aspectos técnicos y creativos. El argumento para la denominación de estos premios vino de la mano del director artístico Ramiro Gómez, señalando que Goya ${ }^{\circledR}$ había tenido un concepto pictórico cercano al cine y varias de sus obras más representativas tenían casi un tratamiento secuencial.

Junto a estos premios, cabe mencionar otros actos organizados por la Academia que también generan documentación cuya gestión y tratamiento también es competencia del Archivo y que son los siguientes:

- Oscar (1986 - actualidad). Acto en el que se da a conocer la selección de películas que optan a representar a nuestro país en la edición de los Premios Oscar de Hollywood.

- Ariel (2010 - actualidad). Acto en el que la Academia escoge la película española candidata a representar a España en los premios Ariel de la academia mexicana. Desde la edición de 2010, este título se escoge por el mismo procedimiento y en los mismos plazos que la cinta que opta a los Premios Oscar.

- Fundación Ayuda contra la Drogadicción (FAD). Premio por su campaña de proyecciones cinematográficas para niños como parte de un programa basado en la cultura como herramienta de prevención. S.M. la reina doña Sofía, su presidenta de honor, recogió el premio en la sede de la propia Fundación.

- Homenajes (2010 - actualidad). La Academia celebra con carácter anual una serie de homenajes a profesionales del cine que por diversas razones no han competido por un premio Goya, pero que cuentan con una larga trayectoria al servicio de la cinematografía. Los homenajeados pasan automáticamente a formar parte de la Academia como miembros asociados.

El Archivo tiene como función principal la reunión, organización, análisis y gestión de la documentación (textual, gráfica, fotográfica y audiovisual) referida a cada uno de estos eventos y premios otorgados por la Academia de Cine a lo largo de su historia. La gestión de la documentación generada en el marco de estos actos tiene como objetivo servir de apoyo a distintas áreas de la institución y constituye un factor clave para la actividad de la Academia y el desempeño de sus funciones.

El sistema de organización y clasificación aplicado en el Archivo para esta documentación se estructura en diez categorías temáticas, que responden a la denominación de los premios y eventos: Premios Goya, Medalla de Oro, Premio González Sinde; Premio Muñoz Suay; Premio Segundo de Chomón; Oscar; FAD; Otros eventos; Personalidades y Academia (institucional).

\section{LOS PREMIOS GOYA. PROCESO DE GESTIÓN DOCUMENTAL}

Constituye el conjunto documental más importante del Archivo, tanto por el contenido como por el volumen de material que genera. La participación de las películas en los denominados Premios Goya está condicionada a la acreditación de distintos requisitos establecidos en las bases de la convocatoria así como la presentación por parte de las productoras de una serie de documentos y materiales en la sede de la Academia. La no entrega de la documentación requerida puede suponer la exclusión de la película de esta convocatoria.

\subsection{Ingreso de la documentación}

En los artículos 6 y 7 de las bases de la convocatoria se establece la documentación que las productoras deben presentar en la Academia para participar en esta categoría de Premios y que serán objeto de tratamiento y análisis documental por parte del Archivo. A continuación se detalla la documentación y materiales que deben entregar las productoras de acuerdo a las bases ${ }^{4}$ para concurrir en la 30 edición de los Premios Goya 2016:

1. Formulario oficial de créditos de cada película cumplimentado, sellado y firmado por el productor.

2. Títulos de crédito completos, sinopsis de la película y cartel en formato digital.

3. Copia del informe de taquilla con la fecha de estreno y permanencia en sala que consta en el Instituto de la Cinematografía y de las Artes Audiovisuales (ICAA) o en el órgano competente en las respectivas Comunidades Autónomas.

4. Certificado de distribución de la película expedido por el ICAA u organismo autonómico competente y certificado de las empresas distribuidoras y/o exhibidoras (para películas no estrenadas al cierre de la inscripción).

5. Tres copias de la película en formato DVD o Blu-Ray.

6. Cinco carteles originales de la película.

7. Una memoria USB (pendrive), tarjeta de memoria o disco duro que contenga la siguiente documentación:

a) Material promocional:

- Cartel de la película en formato digital TIF, JPG o EPS (mínimo 300 ppp). 
- Fotografías de la película, del rodaje y del director (mínimo 300 ppp).

- Clips, making of, pressbook y afiches.

b) Otros materiales: rodillo final, ficha técnica, ficha artística, diseños de vestuario y diseños de escenografía.

8. Un archivo de audio en formato mp3 conteniendo un máximo de cuatro minutos de la música original de la película.

9. Un archivo en formato mp3 por cada una de las canciones originales presentadas, en el caso de que se concurra al Premio Goya ${ }^{\circledR}$ a la Mejor canción original.

10. Copia en $35 \mathrm{~mm}$ o un $\mathrm{DCP}^{5}$ y un Blu-Ray con una copia de la película. Tras hacerse públicas las películas nominadas, los productores dispondrán de un plazo máximo de 48 horas para presentar este material.

\subsection{Registro, selección y clasificación}

Toda esta documentación es gestionada por el Departamento de Gestión de datos, que recibe y registra la documentación, y el Archivo, encargado de su análisis, organización, clasificación y almacenamiento. La primera fase de este proceso se inicia en septiembre y finaliza en noviembre, con la publicación de la lista de películas aspirantes a los Premios Goya. La secuencia del proceso es la que sigue:

- Registro y evaluación de la documentación presentada por las productoras y su adecuación a los requisitos establecidos en las bases.

- Examen del contenido y los criterios de calidad de los materiales (copias digitales de las películas, ficheros de audio, materiales promocionales, etc.).

- Organización y clasificación del material de cada película según la categoría para la que concurre a los Premios. $^{6}$

- Elaboración de la lista de las películas nominadas.

El 12 de noviembre de 2015 la Academia publicaba en su web un listado con las 143 películas candidatas a la 30 edición de los Premios Goya (35 más que en la edición anterior) cuyos finalistas se darán a conocer un mes después en la sede de la Academia. Teniendo en cuenta la documentación presentada por cada productora, se puede valorar el importante volumen de material gráfico, fotográfico y audiovisual que maneja y gestiona el Archivo referido a estos Premios en cada una de sus ediciones.

La preparación de la ceremonia de los Goya es otra de las áreas en las que el Archivo está implicado. Concretamente, se encarga de la búsqueda y selección de muchas de las imágenes que se proyectan en la gala, entre otras, las fotografías de la sección "Los que nos dejaron" que rinde homenaje a los actores y profesionales de la industria fallecidos en el último año.

Finalmente, para la ceremonia de entrega de los Premios Goya, además de la cobertura de RTVE ${ }^{7}$, la Academia cuenta con cuatro fotógrafos distribuidos en los espacios destinados a los medios de comunicación: la alfombra roja, el photocall, la gala y el backstage. A este último espacio sólo tienen acceso los fotógrafos de la Academia, obteniendo material gráfico y audiovisual exclusivo destinado a las publicaciones, especialmente para la revista oficial y para la página web.

\section{TRATAMIENTO DOCUMENTAL}

Para el tratamiento y análisis de toda la documentación generada en el desarrollo de los Premios y eventos, el Archivo de la Academia dispone de un sistema gestión documental (Inmagic) que integra ocho bases de datos según la tipología documental de que se trate: Guiones, Bandas sonoras, Videoteca, Películas, Fotografías, Material gráfico, Libros y Cortos, a las que hay que añadir dos módulos para la gestión de préstamos y las consultas. Para cada tipo de material se ha diseñado una ficha catalográfica.

La flexibilidad y capacidad de este programa permite el uso de campos y registros amplios y sin límite de caracteres además del enlace entre las distintas bases de datos de un modo relacional. Los registros de cada base de datos tienen un conjunto de campos comunes y otros específicos en función del tipo de material. En el caso de la documentación fotográfica el registro integra las siguientes informaciones: Identificador, Signatura, Fecha de Catalogación, Fecha de modificación, Clasificación, Evento, Lugar evento, Fecha de evento, Fotógrafo, Año, Soporte, Color, Título, Subtítulo, Descripción, Descriptores, Uso, $\mathrm{N}^{\circ}$ de fotos. La unidad de descripción son tanto reportajes como fotografías.

El número de descriptores asociados a cada fotografía es variable pero suele integrar: fecha, fotógrafo, evento/tipo de premio/número de edición; nombre y apellidos de las personas representadas. 
La consulta por "Películas" integra todas las informaciones de todos los formularios ofreciendo en los resultados todos los materiales (fotos, material gráfico, guiones, banda sonora, libros, etc.) relacionados con el título consultado y disponibles en el Archivo de la Academia.

\subsection{Acceso y consultas}

Según los datos facilitados por el departamento de Biblioteca y Archivo, en el año 2014 se registraron un total de 151 consultas - un 4\% menos que en 2013- efectuadas por distintos medios siendo el correo electrónico el más utilizado (72\%), seguido del teléfono (23\%) y las consultas presenciales (5\%).

Los datos recogidos en los años 2013 y 2014 coinciden al señalar que los temas de consulta más solicitados son las biografías y filmografías de distintas personalidades relacionadas con la cinematografía (31\%), los Premios Goya (24\%) así como información sobre películas (22\%) (Gráfico 2).

\section{Temas de consulta 2014}

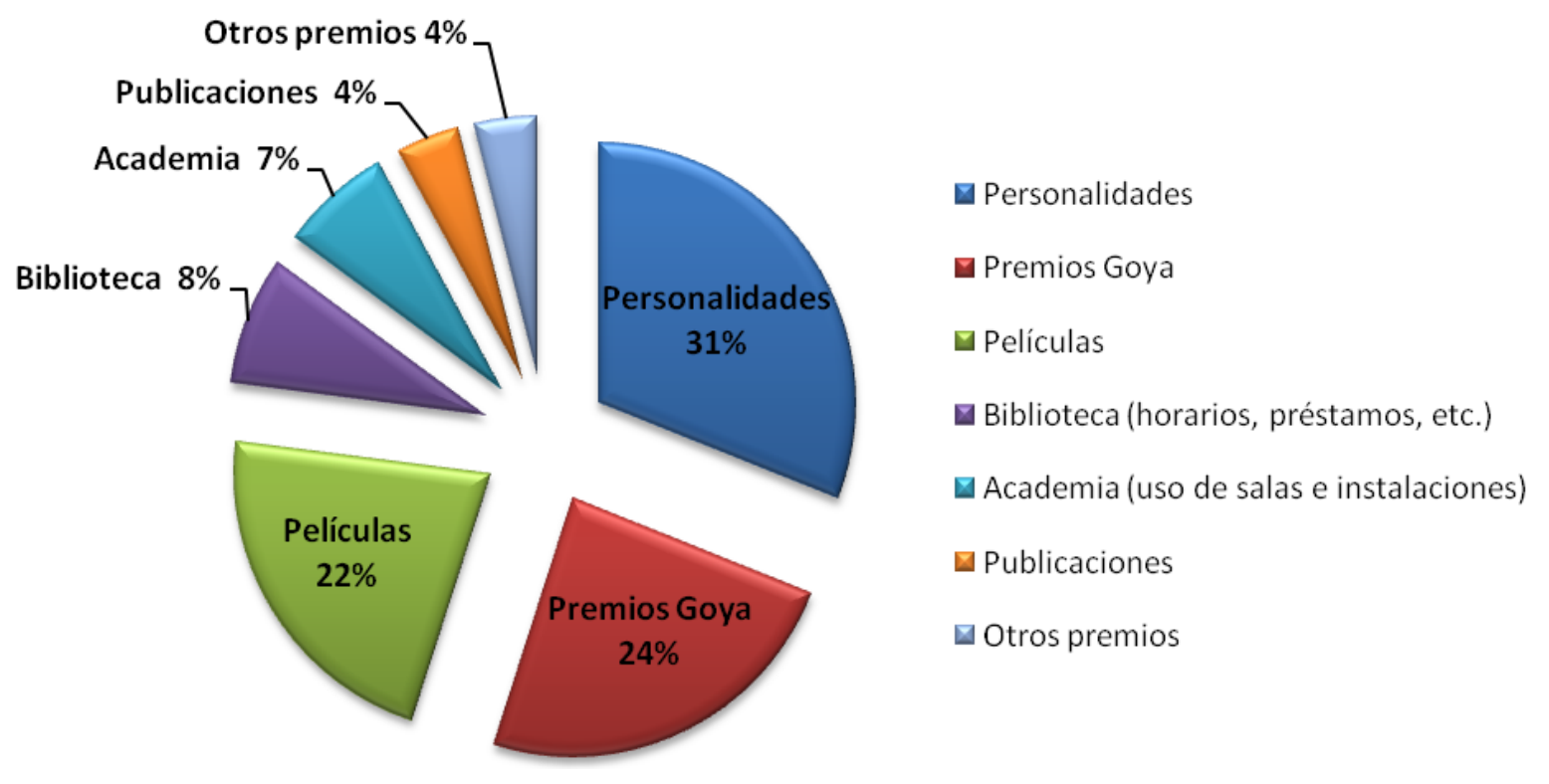

Gráfico 2. Consultas en los servicios de Biblioteca y Archivo de la Academia de Cine. Fuente: Elaboración propia a partir de los datos facilitados por la Academia de Cine.

En cuanto a la procedencia de las consultas un 32\% son de origen interno, es decir, de la propia Academia de Cine. Las consultas externas corresponden a usuarios con diferentes perfiles, principalmente medios de comunicación (15\%), Académicos (11\%) e instituciones como la Filmoteca Española o la Sociedad General de Autores (SGAE) con un $11 \%$. Le siguen investigadores y estudiantes (10\%), particulares (10\%), festivales (6\%) y productoras (5\%) (Gráfico 3). 


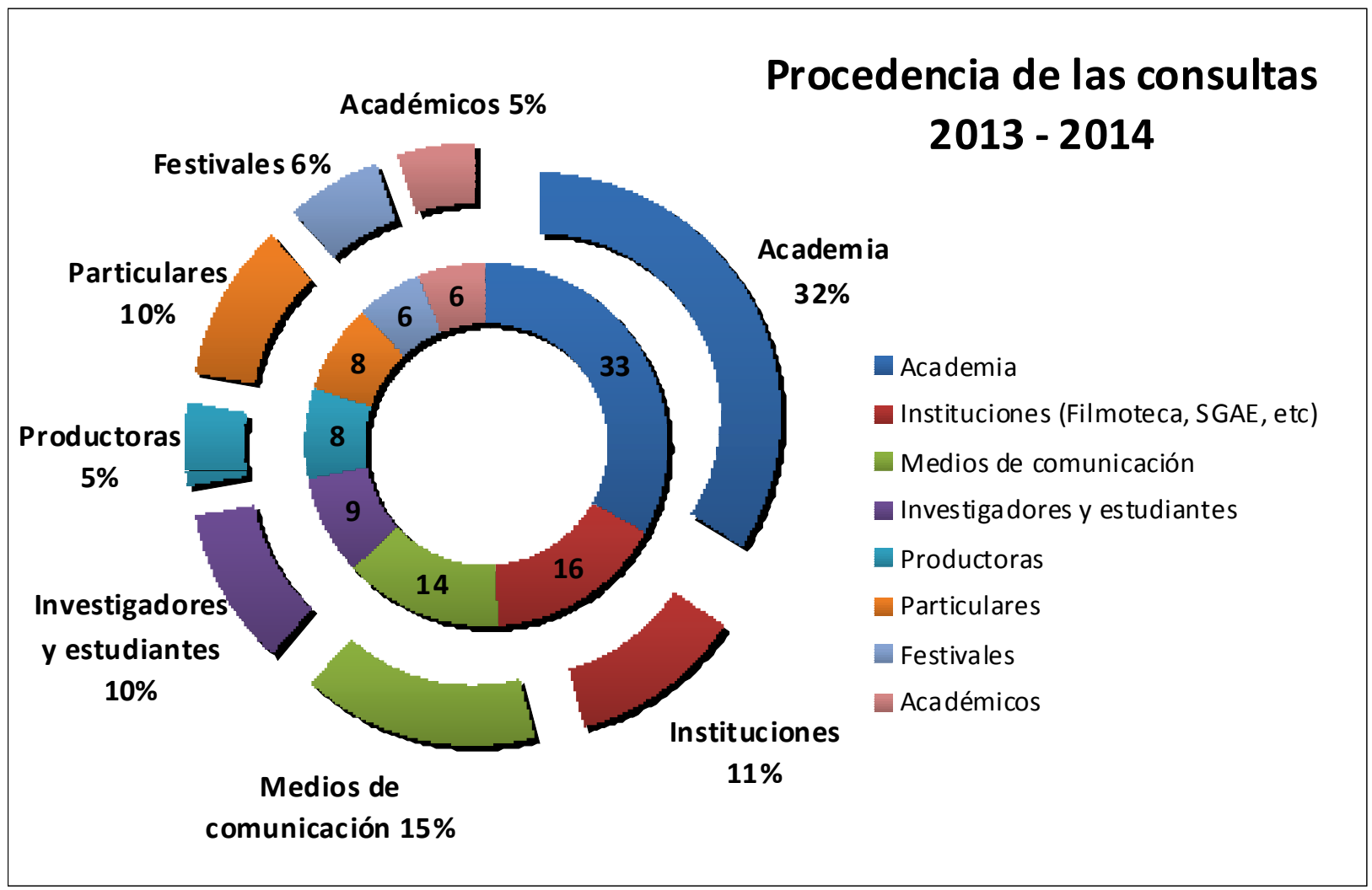

Gráfico 3. Perfil de usuarios y procedencia de las consultas correspondientes al año 2013 (ć́rculo interno) y 2014 (círculo externo). Fuente: Elaboración propia a partir de los datos facilitados por la Academia de Cine.

\section{DIFUSIÓN Y VISIBILIDAD}

La web de la Academia se estructura en cinco secciones: La Academia, Premios, Publicaciones, Programación cultural y Prensa. Las imágenes acompañan a la información textual y las noticias, pero no son un contenido específico.

La sección "Prensa” (mediante registro) facilita el acceso a material gráfico con opciones de visualización y descarga de las notas de prensa y las fotografías. Hasta la fecha de este estudio, dispone de un total de 280 notas de prensa, desde 17 de junio de 2011 hasta la actualidad, siendo la más reciente del 17 de noviembre de 2015. Cada nota está acompañada de título, fecha y resumen, e incorpora las opciones "Ver nota completa” y "Descarga” en formato pdf.

En cuanto a material gráfico, incluye 18 galerías de imágenes con un total de 133 fotografías, desde el 11 de noviembre de 2010 hasta el 9 de septiembre de 2013. Corresponden a entregas de premios como la Medalla de Oro, lectura de los Premios Ariel, películas precandidatas a los Óscar, exposiciones y entrevistas entre otros eventos. Cada galería se presenta con una miniatura, título de la galería, fecha y número de fotos que contiene (Figura 2). Las imágenes incluyen el copyright con el nombre del autor/fotógrafo y la opción de “Descarga” en formato jpg. 


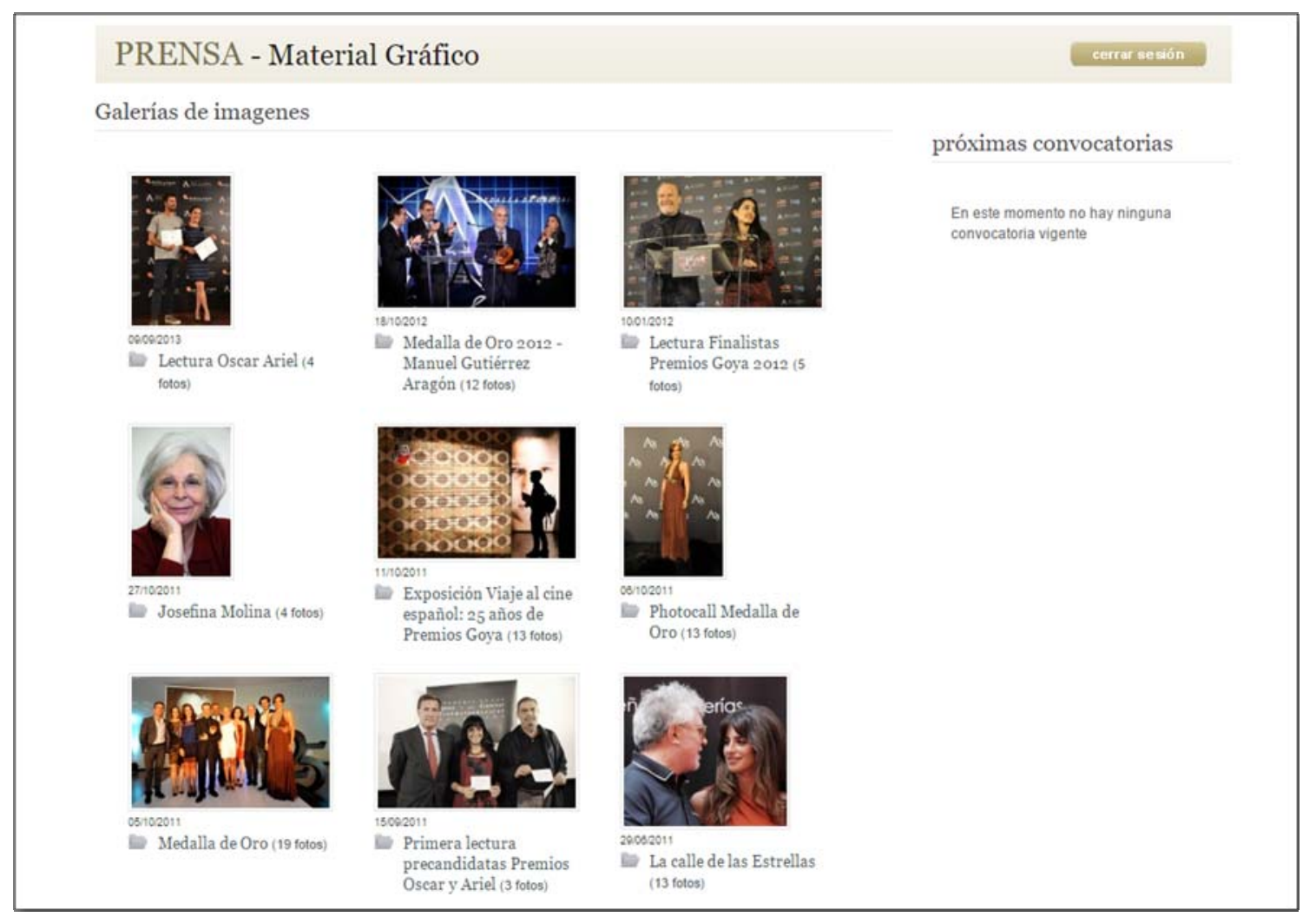

Figura 2. Web de la Academia de Cine. Acceso a las galerías de imágenes desde la sección Prensa. $<$ http://www.academiadecine.com/prensa/material_grafico.php> [Consulta: 8 de diciembre de 2015].

La sección dedicada a los premios es la que concentra un mayor volumen de documentación gráfica, especialmente los Premios Goya, que disponen de una página oficial dentro de la web de la Academia donde se ofrece información estructurada en seis apartados: El Premio, Las Canditaturas, Los Nominados, Los Ganadores, La Gala y Actualidad. Este último apartado incluye el acceso a las noticias y fotogalerías relacionadas con la $30^{\text {a }}$ edición de los Premios. Hasta la fecha de este análisis sólo dispone de una fotogalería con cuatro imágenes (Figura 3).

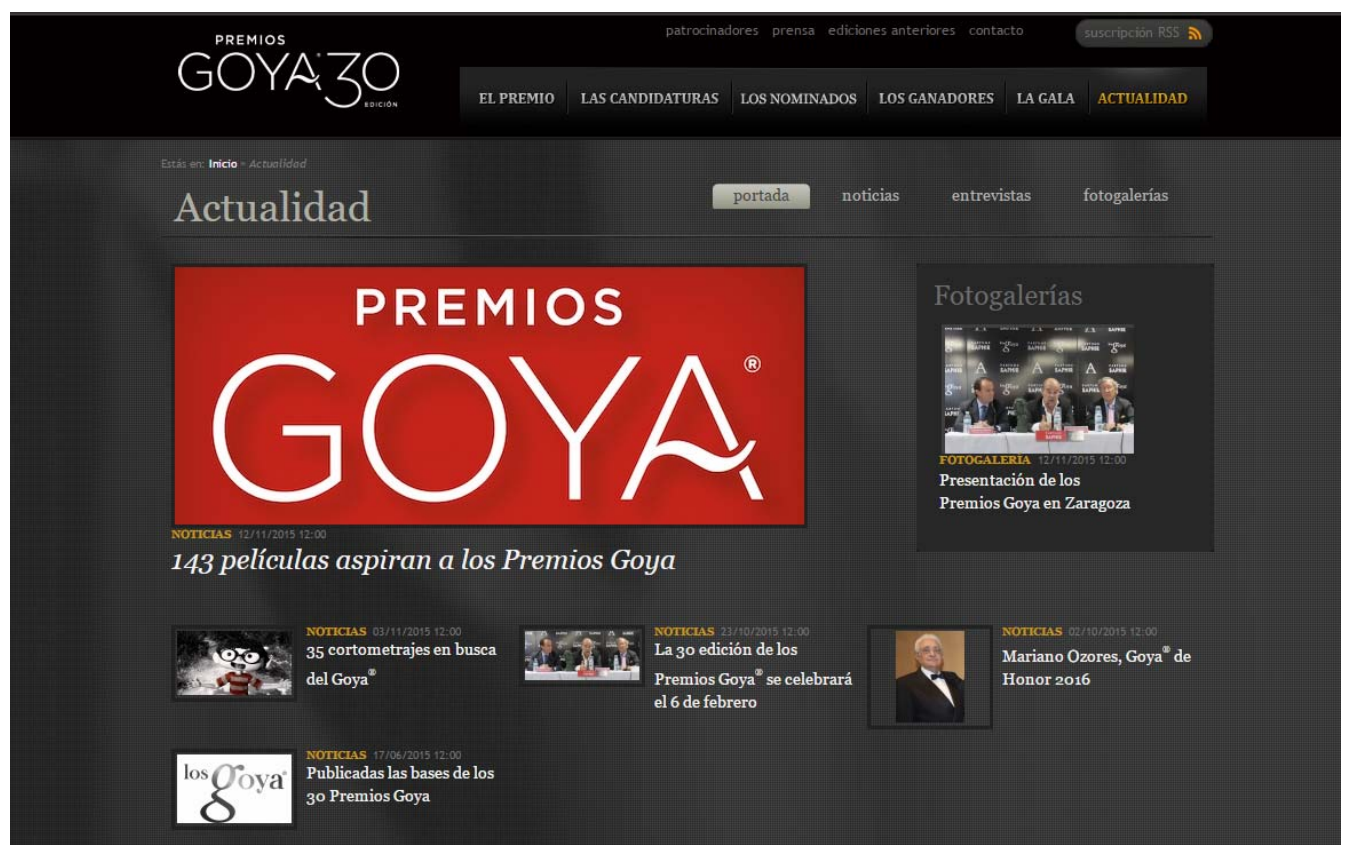

Figura 3. Página oficial de los Premios Goya. Sección “Actualidad” con acceso a las fotogalerías. $<$ http://www.premiosgoya.com> [Consulta: 8 de diciembre de 2015]. 
Desde la página de los Premios Goya se accede además a un enlace para la prensa donde se facilitan las acreditaciones para el evento y el acceso a las notas de prensa y recursos gráficos (vídeos y fotografías) relacionado con los premios. En la fecha en que se realiza este análisis la web ofrece la visualización y descarga de dos vídeos y 135 fotografías correspondientes a ediciones anteriores de los premios, concretamente de los años 2013 , 2014 y 2015 (Figura 4).

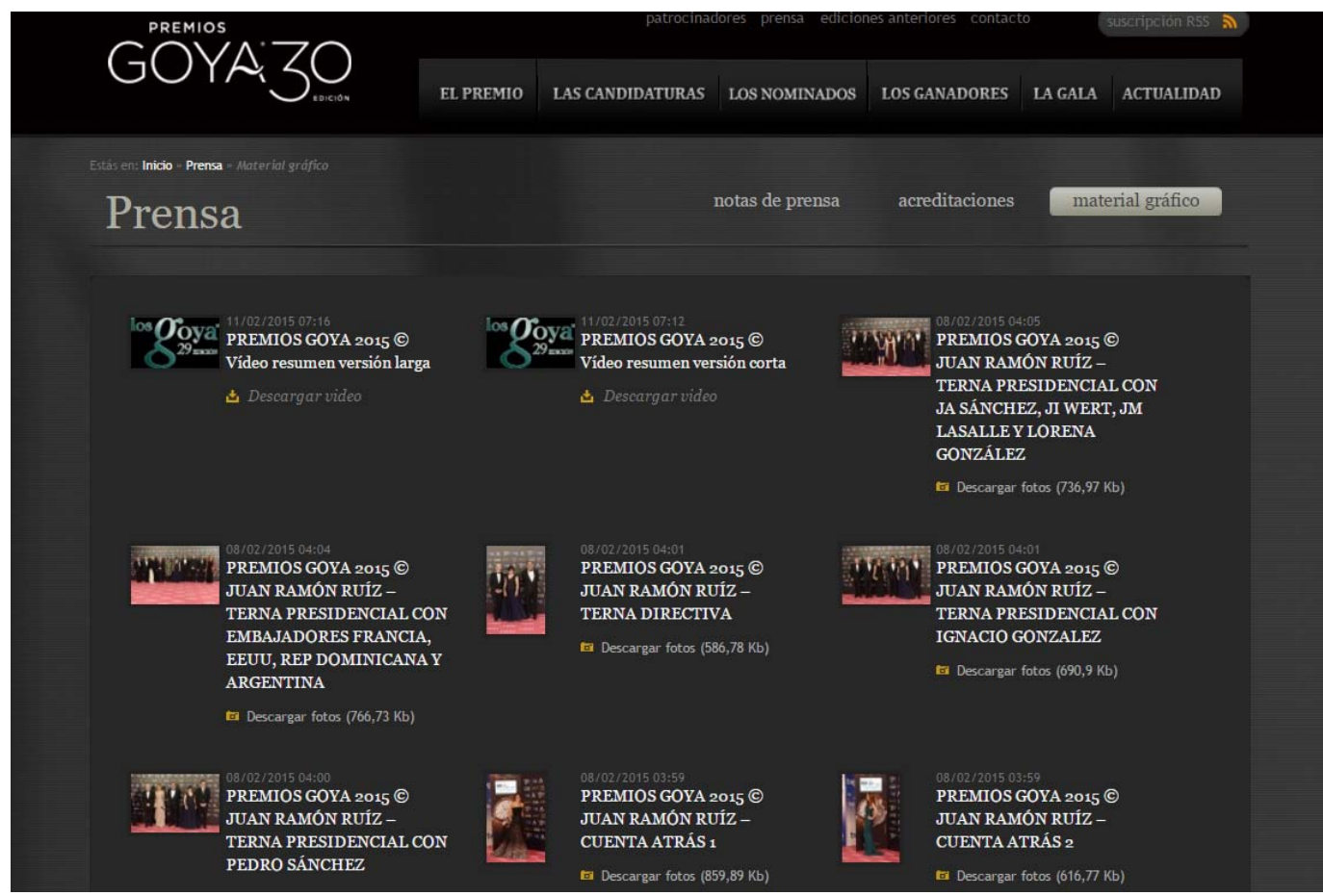

Figura 4. Página oficial de los Premios Goya. Acceso al material gráfico desde el área de prensa. <http://www.premiosgoya.com/prensa/recursos-graficos> [Consulta: 8 de diciembre de 2015].

Para cumplir con sus fines de promoción y difusión del cine español la Academia ha editado una serie de publicaciones impulsadas por José Luis Borau. La primera revista de la Academia nació en 1991 con periodicidad trimestral editando veinticinco números hasta 1998. En 1999, pasó a ser semestral y a partir del número 33 anual. Su último número se editaría en diciembre de 2004.

En 1997, con motivo de las celebraciones del I Centenario del Cine Español, la Academia puso en marcha Cuadernos, una publicación sin sujeciones de periodicidad. Se han publicado catorce números, correspondiendo el último al año 2005.

La actual revista Academia es la evolución de la primera revista que publicó esta asociación. Con una periodicidad bimestral está disponible en formato impreso y desde febrero de 2014, en versión electrónica además de una aplicación gratuita para iPad.

La labor editorial de la Academia se completa con la publicación de guiones premiados en los Goya, monografías y obras de consulta como el Diccionario del cine español. 


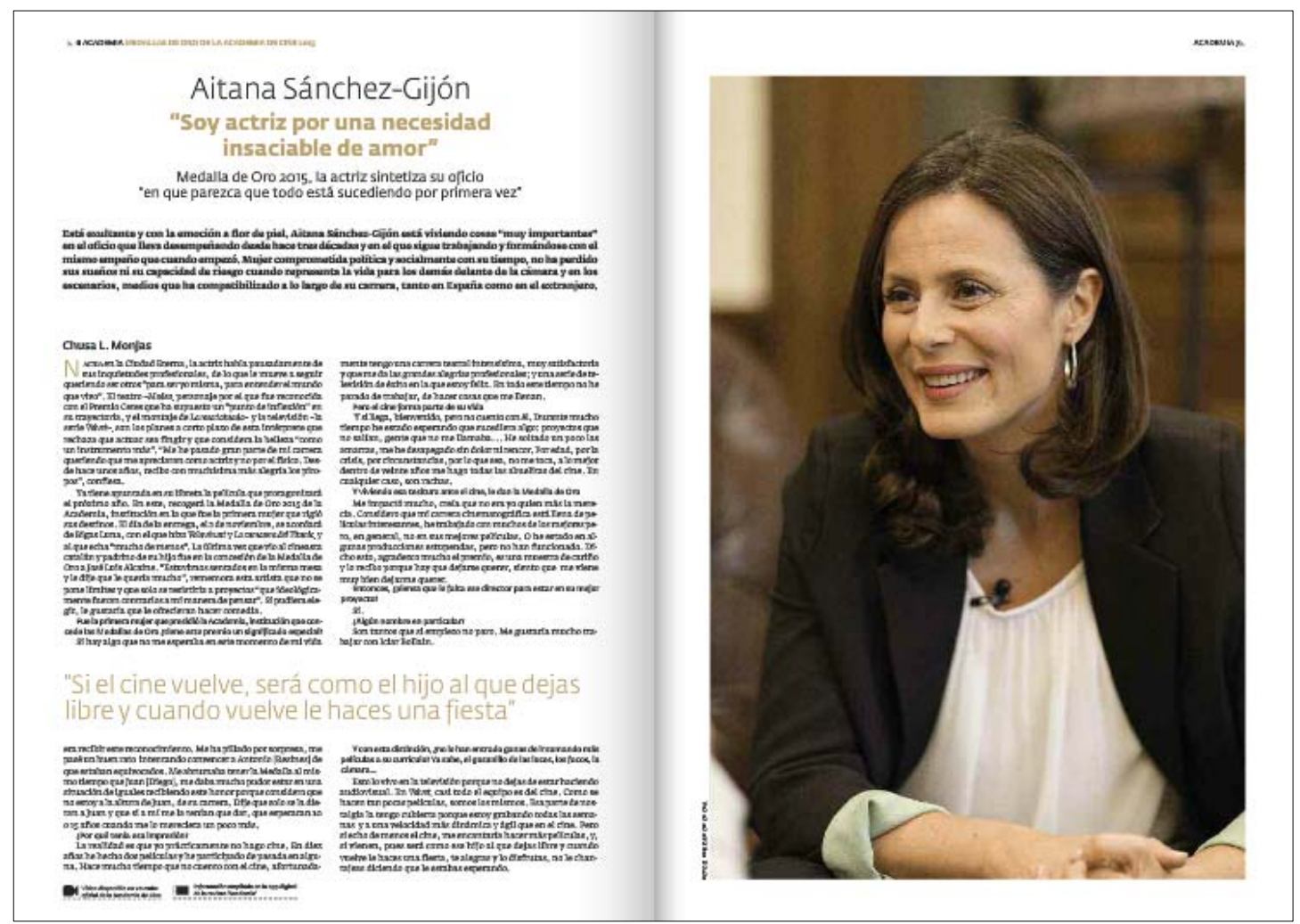

Figura 5. Revista Academia, n $^{\circ}$ 216, noviembre 2015.

Las exposiciones de carácter conmemorativo son otro espacio propicio para la difusión de este patrimonio documental como "Viaje al Cine Español 1987- 2011” con motivo del 25 aniversario de los Premios Goya que hacía un recorrido por los últimos veinticinco años del cine español a través de recreaciones de cada una de las cintas premiadas con el Goya a la mejor película, incluyendo en cada escenografía materiales vinculados a cada una de las películas (fotografías, diseños de producción, vestuario, maquetas, etc.). A partir de sus fondos de archivo, especialmente los fotográficos, también se han realizado las publicaciones conmemorativas 20 años de Premios Goya (Pérez Granado, 2006) y Viaje al cine español. 25 años de los Premios Goya (Lunwerg, 2011).

Otro ejemplo es la exposición “50 años de La tía Tula” (Madrid, 2014), que parte del material fotográfico procedente de los archivos de Miguel Picazo y recupera las escenas más emblemáticas de la película, incluyendo las fotografías tomadas durante el rodaje, afiches y documentos originales vinculados con su filmación. 


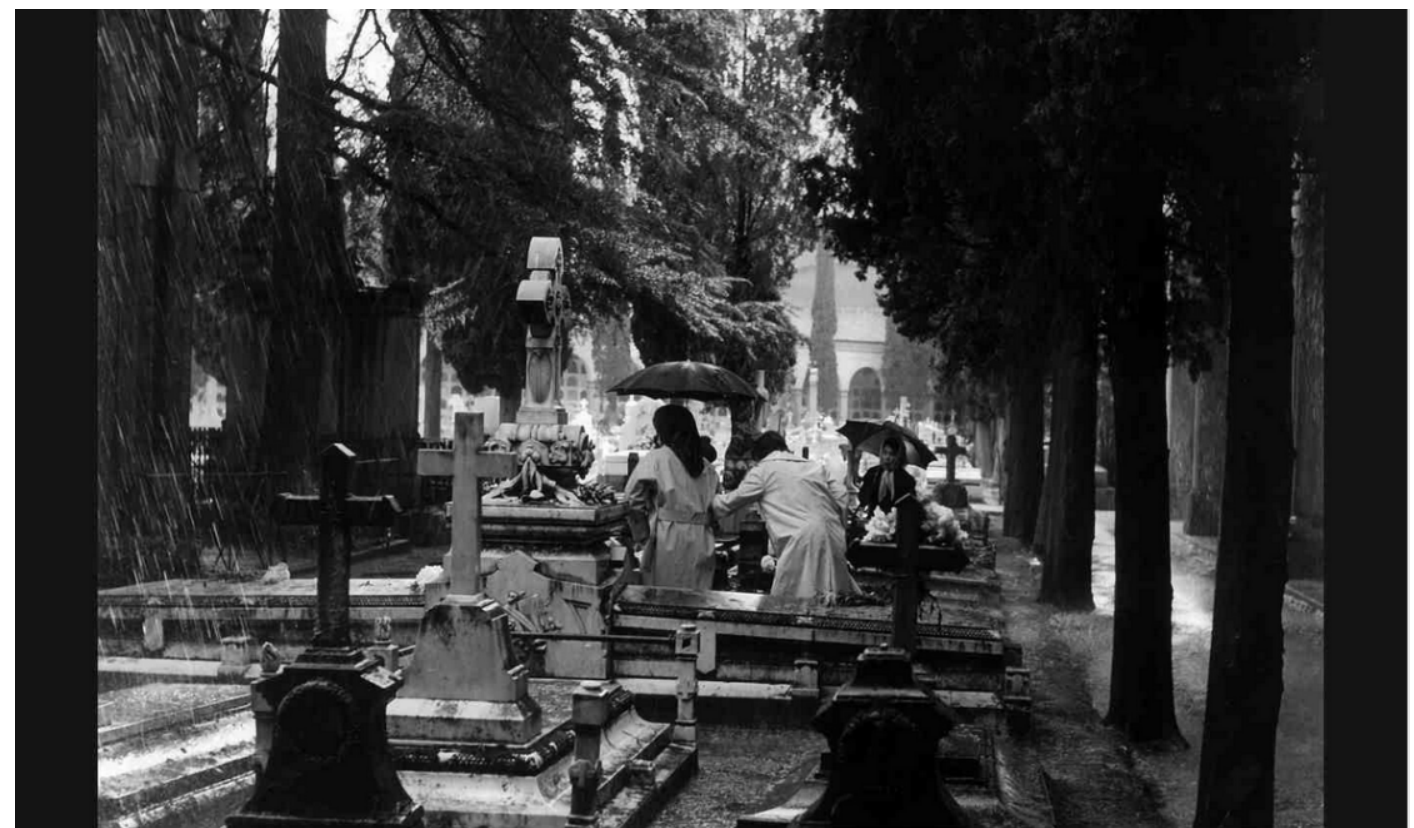

Figura 6. Exposición “50 años de La tía Tula”. Fotografía tomada durante el rodaje y eliminada en el montaje final.

El Berlanga Film Museum (BFM) es otro proyecto de difusión del patrimonio cinematográfico en el que ha colaborado la Academia de Cine, creado para facilitar el acceso y consulta online de la biografía, obra cinematográfica, literaria y cultural de Luis García Berlanga, así como las reflexiones teóricas y críticas sobre su trabajo.

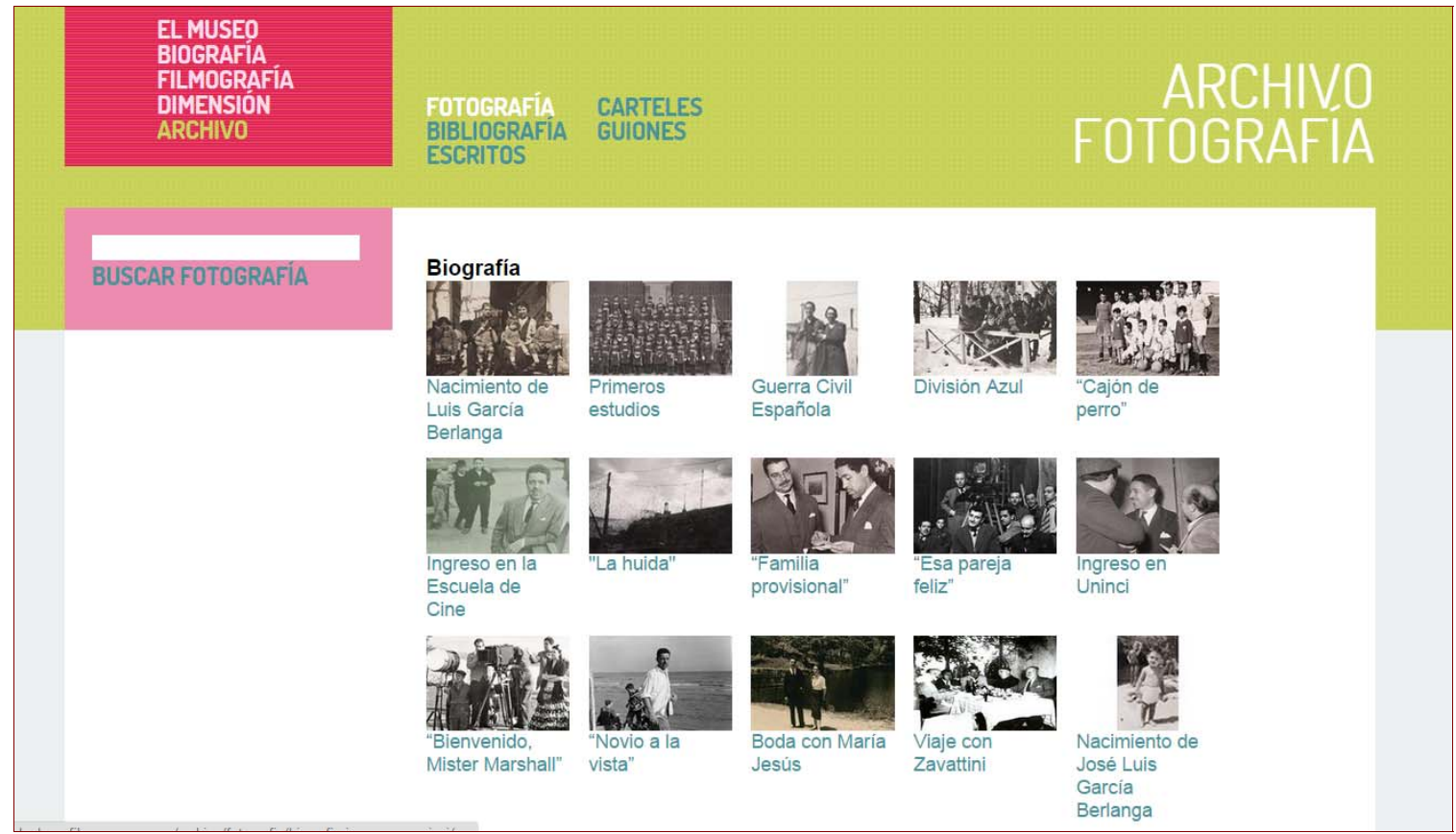

Figura 7. Berlanga Film Museum. Biografía y archivo fotográfico de Luis García Berlanga. $<$ http://www.berlangafilmmuseum.com/archivo> [Consulta: 8 de diciembre de 2015].

Se puede considerar un proyecto pionero en cuanto que no existe en Europa un museo online dedicado íntegramente a la figura de un cineasta. En las principales bases de datos internacionales sobre cine -IMDB, Film Affinity, All Movie Guide, Movie Review- pueden encontrarse algunas web de carácter monográfico sobre ciertos cineastas, que han sido creadas por asociaciones culturales o fundaciones vinculadas a grandes maestros del cine, sin embargo, estas webs no han sido concebidas como un museo virtual. 
El propósito del Berlanga Film Museum es albergar de forma rigurosa y exhaustiva todo tipo de informaciones, documentos, imágenes y archivos fílmicos y sonoros para conocer más a fondo la figura del cineasta. Como centro de documentación, el BFM pretende convertirse en la base de datos de referencia sobre el director valenciano dirigida a investigadores, historiadores cinematográficos y aficionados al cine.

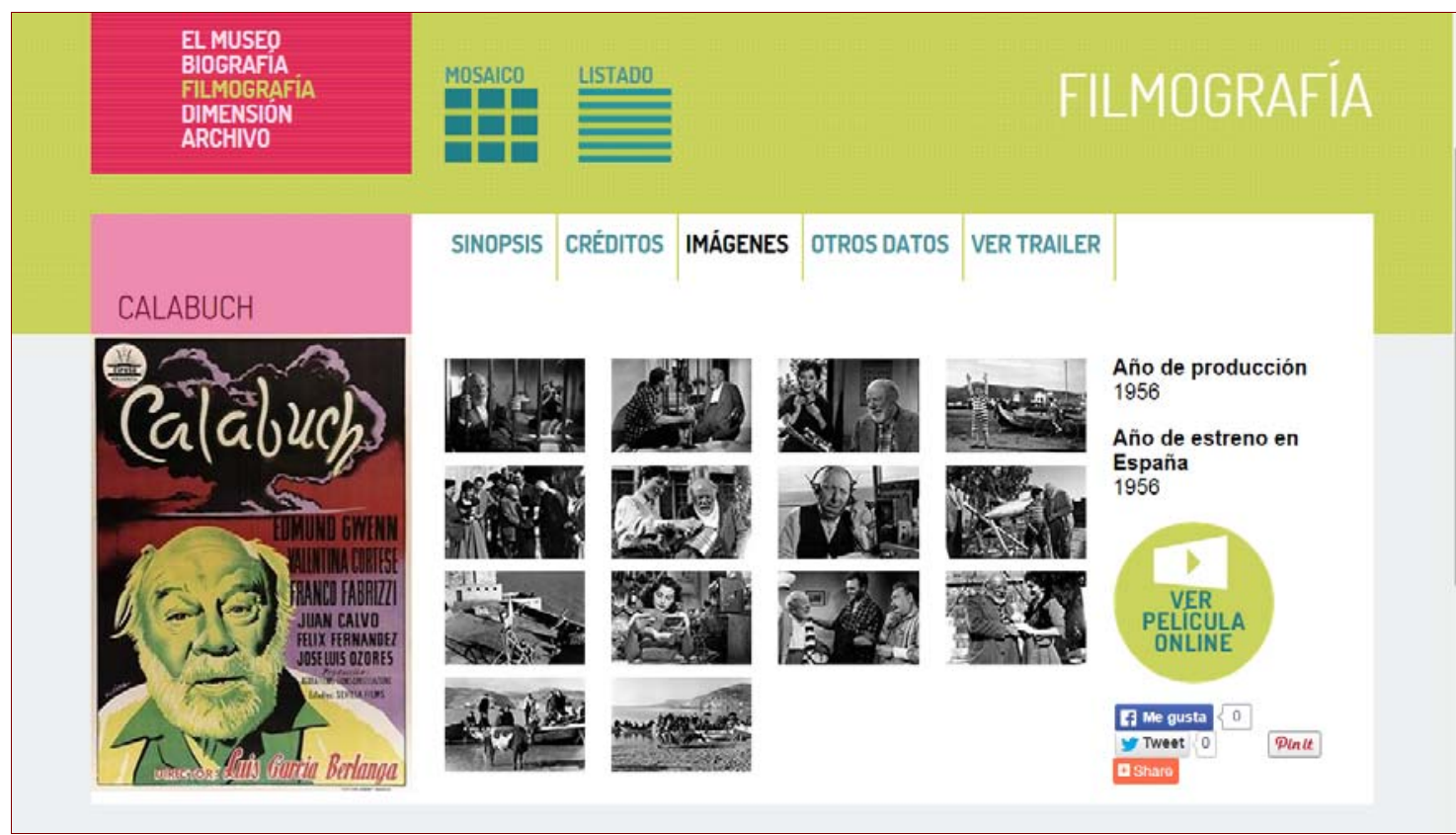

Figura 8. Berlanga Film Museum. Sección Filmografía y acceso a la sinopsis de la película, títulos de crédito, imágenes, cartel, tráiler y visionado online. <http://www.berlangafilmmuseum.com/filmografia/calabuch> [Consulta: 8 de diciembre de 2015].

\section{CONCLUSIONES}

El servicio de Biblioteca y Archivo de la Academia de Cine trabaja desde su creación para contribuir a la promoción, conservación y difusión de la producción contemporánea. El traslado a las nuevas dependencias, en el año 2010, ha servido para disponer de unas instalaciones más adecuadas para cumplir con sus objetivos y abordar una oferta de actividades y servicios más centrada en profesionales, investigadores y ciudadanos.

El estudio presenta información de gran interés para investigadores y profesionales relacionados con la cinematografía y con la cultura de la imagen. Se dan a conocer fondos y colecciones, la tipología documental y los procedimientos de análisis documental. Así mismo se dan a conocer los contenidos y la estructura del Archivo de la Academia de Cine que reúne toda la documentación generada por la institución en el desempeño de sus funciones, y que incluye toda la documentación gráfica de los Premios Goya así como otros galardones, homenajes y eventos que la institución viene celebrando a lo largo de sus treinta años de historia.

La información aportada es de gran importancia para los profesionales del sector de la comunicación cultural, especialmente para los medios de comunicación, ya que algunos de los fondos conservados son una fuente de información excepcional en algunos casos, susceptibles de realizar futuros trabajos de investigación. En este sentido, los resultados del estudio proporcionan valiosa información sobre fondos hasta ahora desconocidos de gran interés para investigaciones sobre figuras destacadas del cine español (fondos de Raquel Rodrigo e Imperio Argentina), crítica de cine (fondo Juan Carlos Frugone) y dirección artística (fondo Eduardo Torre de la Fuente), entre otros.

El estudio realizado pone de relieve el papel activo de la Biblioteca y el Archivo de la Academia en la gestión documental, conservación y promoción del cine español. Muestra de ello es su valioso fondo especializado y su catálogo online; otro buen ejemplo es el Archivo en su labor de tratamiento, análisis documental y gestión de contenidos para su difusión en la web de la Academia y, de un modo específico en la página oficial de los Premios Goya; así como en la revista Academia, publicación oficial de la institución. 
La Academia de Cine tiene un papel estratégico como referente y ente experto para asesorar a la industria cinematográfica española y contribuir a la investigación y formación de los profesionales que aportan el talento, la creatividad y la experiencia en el sector cinematográfico, tanto en la creación, producción y comercialización de contenidos audiovisuales para cine o televisión, como en el uso de estos contenidos en nuevos soportes y medios (videojuegos, publicidad, aplicaciones móviles, internet, etc.).

Los profesionales en formación, pueden encontrar en la Biblioteca y Archivo de la Academia de Cine un aliado en el acceso a contenidos especializados de interés patrimonial, pero también para la investigación en las artes cinematográficas y sus técnicas, completando la oferta formativa sobre la materia con un centro de información de carácter único.

La unidad de documentación de la Academia de Cine que integra el servicio de Biblioteca y Archivo ofrece soporte a la Filmoteca Española en su compromiso de facilitar el acceso y la difusión de las colecciones y fondos documentales que conservan. En este sentido, la Biblioteca y el Archivo de la Academia han dado respuesta para agregar contenidos únicos y especializados y facilitar la transferencia de conocimiento, innovación y promoción de la cinematografía, un sector económico estratégico en la cultura y la industria de nuestro país.

\section{NOTAS}

${ }^{1}$ Este estudio ha sido realizado gracias a la colaboración e información facilitada por la Academia de Cine y, de un modo especial, por D. ${ }^{a}$ Patricia Viada, coordinadora de los servicios de Biblioteca, Archivo y Documentación de la Academia.

2 Segundo de Chomón (Teruel, 1871- París, 1929) dirigió varios cortometrajes y trabajó para la productora más importante del mundo a principios de siglo, la Phaté Fréres. Estuvo durante mucho tiempo a las órdenes de George Méliès coloreando las películas a mano. Sus trucajes e ilusiones ópticas aparecieron en superproducciones europeas y exploró las posibilidades del stop motion.

3 Alfonso Sánchez Martínez, una de las figuras más representativas de la crítica cinematográfica. Trabajó en La Codorniz, Primer Plano, Cámara, El Alcázar, Hoja del Lunes, ABC y Tele-Radio y en el programa Revista de Cine, un clásico de la segunda cadena cuando sólo existían en España dos canales de televisión.

${ }^{4}$ Publicadas por la Academia de Cine el 17 de junio de 2015 y disponibles en la web oficial.

${ }^{5}$ DCP (Digital Cinema Package) es el estándar de exhibición cinematográfico en todo el mundo, promovido por la DCI (Digital Cinema Initiatives), una asociación de los grandes estudios de cine que busca una gran calidad de exhibición como la copia de 35 mm, a la vez que un sistema de seguridad anticopia para prevenir el pirateo.

6 Los Premios Goya contemplan 28 categorías: Mejor película; Mejor dirección; Mejor dirección novel; Mejor guión original; Mejor guión adaptado; Mejor música original; Mejor canción original; Mejor interpretación masculina protagonista; Mejor interpretación femenina protagonista; Mejor interpretación masculina de reparto; Mejor interpretación femenina de reparto; Mejor actor revelación; Mejor actriz revelación; Mejor dirección de producción; Mejor dirección de fotografía; Mejor montaje; Mejor dirección artística; Mejor diseño de vestuario; Mejor maquillaje y peluquería; Mejor sonido; Mejores efectos especiales; Mejor película de animación; Mejor película documental; Mejor película europea; Mejor película iberoamericana; Mejor cortometraje de ficción; Mejor cortometraje documental y Mejor cortometraje de animación. Además, se hace entrega del Goya de honor que reconoce toda una vida de dedicación al cine a un cineasta de cualquier especialidad.

${ }^{7}$ Radio Televisión Española tiene los derechos de emisión de la gala durante cinco años. Tras este periodo se puede disponer de este material.

\section{BIBLIOGRAFÍA}

AA. VV. Viaje al cine español. 25 años de los Premios Goya. Barcelona: Lunwerg, 2011.

Academia de Cine. 30 Premios Goya. Bases de la convocatoria, 2015 <http://www.premiosgoya.com/wpcontent/uploads/2016/01/BasesGoya30.pdf> [Consulta: 14 de marzo de 2016].

BAILAC, M. y CATALÀ, M. El documentalista audiovisual. El profesional de la información, 2003, vol. 12, nº 6, p. 486-488.

CUADRA COLMENARES, E. de la. Fuentes de información para el trabajo cinematográfico, Boletín de la ANABAD, 2007, tomo 57, n 2, p. 85-104.

CUADRA COLMENARES, E. de la. Documentación cinematográfica. Barcelona, UOC, 2013. ISBN: 978-8490297735.

DEVESA, D. El cine en la biblioteca: del papel al CD. Métodos de información, 2000, vol. 7, n 38-39, p. 41-46.

GARCÍA CASADO, P. y ALBERICH PASCUAL, J. Filmotecas en la encrucijada. Función y expansión de la actividad filmotecaria en el nuevo escenario digital. El profesional de la información, vol. 23, nº 1, 2014.

LÓPEZ DE SOLÍS, I. El film researcher. Barcelona: UOC, 2013.

LÓPEZ HERNÁNDEZ, M.A. Análisis cronológico-secuencial del documento fílmico. Documentación de las Ciencias de la Información, 2003, n 26, p. 261-294.

LÓPEZ YEPES, A. Los centros de documentación cinematográfica: panorama actual. Documentación de las Ciencias de la Información, 1992, n 15, p. 219-258. 
Cine y fuentes de información en internet: panorámica documental y repertorio básico de sitios web. Métodos de información, julio 2000, vol. 7, n 38-39, p. 64-75.

Documentación y bases de datos cinematográficas. Cuadernos de Documentación Multimedia, 2001, nº 11.

Filmotecas y archivos fílmicos en línea: producción, difusión, interconexión y posicionamiento en internet. Scire: representación y organización del conocimiento, 2008.

LÓPEZ YEPES, A.; CUADRA COLMENARES, E. de la; SÁNCHEZ JIMÉNEZ, R. y PÉREZ AGÜERA, J.R. El cine en la era digital: Aplicaciones de la documentación cinematográfica. Madrid: Fragua, 2006.

PH. Boletín del Instituto Andaluz del Patrimonio Histórico. Especial monográfico: Patrimonio cinematográfico, 2005, $\mathrm{n}^{0} 56$.

PINTANEL, M.A. 11 anys de catalogació de fotos fixes a la Filmoteca de Catalunya. 11es Jornades Antoni Varés Imatge i Recerca. Girona: Ajuntament de Girona, 2010.

SUAREZ, G. La documentación de un guión cinematográfico: Más allá de las cajas de cristal. Revista de Estudios Literarios, 2008, $\mathrm{n}^{\circ} 39$.

PÉREZ GRANADO, V. 20 años de Goyas al cine español. Madrid: Aguilar, 2006.

TORRADO MORALES, S. Accesibilidad de los usuarios españoles a los fondos cinematográficos, en VII Jornadas Españolas de Documentación, 2000, p. 312-330.

VALLE GASTAMINZA, F. del. Patrimonio cinematográfico. En: MARCOS RECIO, J.C. Gestión del patrimonio audiovisual en medios de comunicación. Madrid: Síntesis, 2013, p. 111-130.

ZABALA VÁZQUEZ, J. y SÁNCHEZ GALÁN, M.B. Documentos publicitarios en archivos fílmicos: importancia, escenario actual y dificultad de análisis. El profesional de la información, enero-febrero 2014, vol. $23, \mathrm{n}^{\circ} 1$. 
Anexo 1. Entrevista realizada a la coordinadora del departamento de Biblioteca y Archivo de la Academia de Cine

1. ¿Cuál es el origen de la Academia de cine?

2. ¿Cómo fue el proceso de creación del departamento de archivo y biblioteca?

3. ¿Cuáles son sus funciones?

4. ¿̇A qué departamentos/áreas presta apoyo el archivo?

5. ¿Qué circuito/itinerario sigue la documentación desde que ingresa en la Academia hasta que llega al archivo?

6. ¿Qué base de datos o sistema de gestión de la documentación utilizan? ¿Cuál es su estructura?

7. ¿Qué usos y aplicaciones tiene la documentación del archivo? ¿Uso interno? ¿Difusión?

8. ¿Cuál es el perfil de los usuarios del departamento de archivo y biblioteca de la Academia?

9. ¿Qué temas y tipología documentos son más demandados?

10. ¿Qué actividades de difusión realizan con la documentación del archivo? 
Anexo 2. Formulario diseñado para el trabajo de campo de la Biblioteca y Archivo de la Academia de Cine

\section{Tipos de fondos}

a. Documentación externa. Tipología

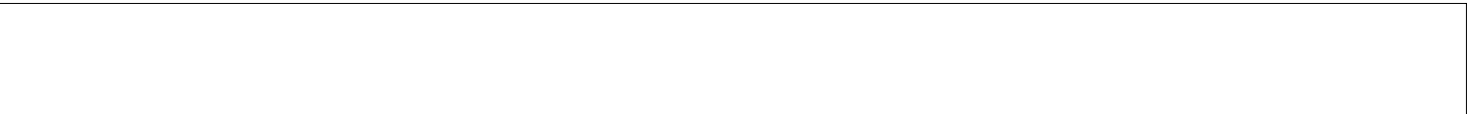

b. Documentación propia. Tipología

\section{Volumen de fondos:}

\section{Fechas extremas de la documentación:}

4. Temas

5. Procedencia/Modo de ingreso

$\square$ Compra

Productoras

Fotógrafos propios

\section{Proceso documental}
a. Ingreso
Área/Departamento:
Procedimiento/Normativa:

b. Tratamiento documental

Área/Departamento:

Procedimiento/Normativa:

c. Difusión

Área/Departamento:

Procedimiento/Normativa:

d. Almacenamiento

Área/Departamento:

Procedimiento/Normativa: 